九州大学学術情報リポジトリ

Kyushu University Institutional Repository

\title{
Transformational Construction of a Protein- producing Strain of Bacillus mesentricus niger
}

Hara, Toshio

Laboratory of Microbial Technology, Faculty of Agriculture, Kyushu University

Fujio, Yusaku

Laboratory of Microbial Technology, Faculty of Agriculture, Kyushu University

Ueda, Se inosuke

Laboratory of Microbial Technology, Faculty of Agriculture, Kyushu University

https://doi.org/10.5109/23750

出版情報: 九州大学大学院農学研究院紀要. 26 (4)，pp.205-211，1982-07. Kyushu University バージョン：

権利関係 : 


\title{
Transformational Construction of a Protein-producing Strain of Bacillus mesentricus niger
}

\author{
Toshio Hara, Yusaku Fujio and Seinosuke Ueda \\ Laboratory of Microbial Technology, Faculty of Agriculture, \\ Kyushu University 46-09, Fukuoka 812 \\ (Received February 5, 1982)
}

\begin{abstract}
A transformant (HS-29) which accumulated a considerable amount of extracellular protein was isolated from Bacillus mesentricus niger no. 6021 which produced RNA extracellularly. Strain HS-29 produced $7.2 \mathrm{mg}$ of protein per $\mathrm{ml}$ of maltose medium for 5 days in liquid shake culture. This strain excreted various kinds of proteins and the amount of exoprotein increased. The amino acid composition of intraand extracellular protein was different. and extracellular protein contained relatively less amounts of alanine and glutamic acid compared with intracellular protein.
\end{abstract}

\section{INTRODUCTION}

It has been known that various microorganisms excrete proteins into the culture media. These proteins are detected as enzymes and toxins (Pollock, 1962; Schaeffer 1969; Heyningen 1970). A great deal of work has also been achieved on the production of enzymes for practical purposes. The mechanism of protein excretion has been a subject of extensive studies because the interest and importance of the problem concerning with individual proteins, knowledge on extracellular informational macromolecules and their formation. But its exact mechanism remained unsolved. Therefore, a systematic study on the excretion of proteins by microbial cells might be valuable in revealing information on extracellular macromolecules.

We were interested in constructing a microorganism capable of excreting and accumulating large amounts of proteins. As a first step in such a study, we tried to construct protein-excreting bacteria by using transformation as genetic technique.

\section{MATERIALS AND METHODS}

\section{Strains and isolation of transformant}

A character for the production of exoprotein in relaxed mutant, Bacillus mesentricus niger no. 6021 (Hara and Ueda, 1981a, 1982a, b) was transferred into strain no. $5603\left(t h r^{-}\right)$obtained from strain no. 6021 with N-methyl-N'nitro-N-nitrosoguanidine by the method of Adelberg et al. (1965). Pseudomonas aeruginosa KYU-1, a DNA-excreting bacteria (Ueda and Hara, 1981; 
Hara and Ueda, 1981b, c, 1982c; Hara et al., 1981), is used as the donor strain.

Transforming DNA was prepared from exponetially growing cells by the method of Saito and Miura (1963), and filtrated through Millipore filter (type HA, pore size $0.3 \mu \mathrm{m}$ ) to remove spores. Transformation experiments were carried out by the method of Yoshikawa (1970).

\section{Medium and culture conditions}

(1) Bacterial growth was determined by measuring optical density (OD) at $660 \mathrm{~nm}$ of appropriately diluted culture broth with water.

(2) RNA samples of precipitates obtained by adding three volumes of 95 \%o ethanol to the supernatant solution of culture broth were subjected to RNA assay by the reaction of orcinol (Mejbaum, 1939) with yeast RNA as standard.

(3) Extracellular protein was estimated as follows: the culture broth was centrifuged to remove cells and an equal volume of $10 \%$ trichloroacetic acid (TCA) was added to the supernatant solution. After allowing to stand for more than $30 \mathrm{~min}$ at room temperature, the precipitate was washed with $5 \%$ TCA two times, collected by centrifugation, dissolved precipitate was analyzed for protein by the method of Lowry et al. (1951) with bovin serum albumin as standard.

(4) Sugars were estimated by the method of Dubois et al. (1956).

(5) Amino acid composition of proteins was determined as follows. The extracellular protein was precipitated by adding equal volume of $10 \%$ TCA to culture supernatant. The preciptitate was dissolved in $0.5 \mathrm{M}$ Tris- $\mathrm{HCl}$ buffer ( $\mathrm{pH}$ 8.0) and dialyzed in a cellophan tube against 5 liters of $0.01 \mathrm{M}$ Tris$\mathrm{HCl}$ buffer ( $\mathrm{pH} \mathrm{8.0)}$ for $24 \mathrm{hr}$. A small quantity of precipitate formed during the dialysis was removed by centrifugation and a crude powder of proteins was obtained by lyophilization of the dialysate. To assay intracellular protein, the cells were washed with $0.05 \mathrm{M}$ phosphate buffer (pH 7.2) and then lyophilized. The protein samples were hydrolyzed in $6 \mathrm{~N} \mathrm{HCl}$ at $124^{\circ} \mathrm{C}$ in sealed tubes for $24 \mathrm{hr}$ and quantitative analysis of amino acid was carried out by using JEOL JLC6AH automatic amino acid analyzer.

(6) Polyacrylamide gel electrophoresis with SDS was performed according to the method of Ames (1974).

\section{RESULTS}

\section{Construction of strain producing extracellular protein}

Transfer of phenotypic threonine nonrequirement $\left(t h r^{+}\right)$from $B$. mesentricus niger no. 6021 to strain no. 5603 by the DNA-mediated transformation was carried out as shown in Fig. 1 . When competent cells of $B$. mesentricus niger no. 5603 were treated with DNA from RNA-producing bacteria, thr transformants appeared on selective plates (Table 1). The number of transformants was proportional to the amount of DNA added. However, the transformation frequencies of $t h r^{+}$with DNA from $P$. aeruginosa KYU-1 were about $1 / 100$ of those with a homologeous DNA from $B$. mesentricus niger no. 6021 . 


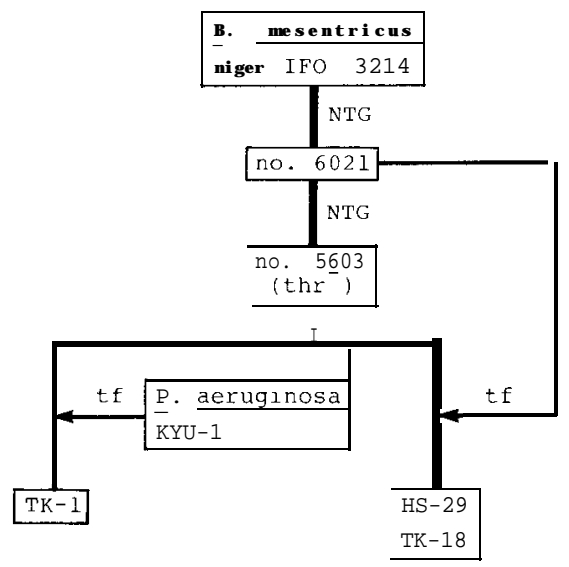

Fig. 1. Construction process of protein-producing bacteria.

Table 1. Comparision of transformation frequency. DNA concentration used was $0.1 \mu \mathrm{g} / \mathrm{ml}$. These experiments were carried out as described in Materials and Methods. After addition of DNA. pancreatic DNase (Boehringer Mannheim $\mathrm{GmbH})(10 \mu \mathrm{g} / \mathrm{ml})$ was added, followed by incubation for $60 \mathrm{~min}$ at $37{ }^{\circ} \mathrm{C}$ and spreading onto minimal agar plates.

\begin{tabular}{|c|c|c|}
\hline Donor strain & Recipient strain & Transformation frequency \\
\hline $\begin{array}{l}\text { B. mesentricus niger no. } 6021 \\
\text { P. aeruginosa KYU-1 }\end{array}$ & $\begin{array}{l}\text { B. mesentricus niger no.5603 } \\
\left(t h r^{-}\right)\end{array}$ & $\begin{array}{l}6.3 \times 10^{-4} \\
1.0 \times 10^{-6}\end{array}$ \\
\hline
\end{tabular}

To isolate protein-producing transformants by the DNA of strain no. 6021 , three $t h r$ transformants were selected. One hundred and five colonies of the transformants were screened for their ability to produce extracellular protein. One of the transformants (HS-29) was selected and used throughout this work (Table 2).

Table 2. Productivity of RNA and protein in the parental strains and representative transformants. Cultivation was carried out under the conditions as described in Materials and Methods.

\begin{tabular}{|c|c|c|c|}
\hline Strain & & $\begin{array}{c}\mathrm{RNA} \\
(\mathrm{mg} / \mathrm{ml})\end{array}$ & $\begin{array}{l}\text { Protein } \\
(\mathrm{mg} / \mathrm{ml})\end{array}$ \\
\hline Donor & $\begin{array}{l}\text { no. } 6021 \\
\text { KYU-1 }\end{array}$ & $\begin{array}{l}4.8 \\
0.8\end{array}$ & $\begin{array}{l}3.4 \\
0.6\end{array}$ \\
\hline Recipient & $\begin{array}{l}\text { no. } 5603 \\
\left(t h r^{-}\right)\end{array}$ & $\begin{array}{l}2.7 \\
3.2\end{array}$ & 5.1 \\
\hline Transformant & $\begin{array}{l}\text { TK-1 } \\
\text { TK-18 } \\
\text { HS-29 }\end{array}$ & $\begin{array}{l}5.2 \\
2: 4\end{array}$ & $\begin{array}{l}3.8 \\
5.2 \\
7.2\end{array}$ \\
\hline
\end{tabular}

\section{Time course of protein production}

The time course of the production of extracellular protein by the transformant (HS-29) was examined. Figure 2 shows the time courses of growth and 


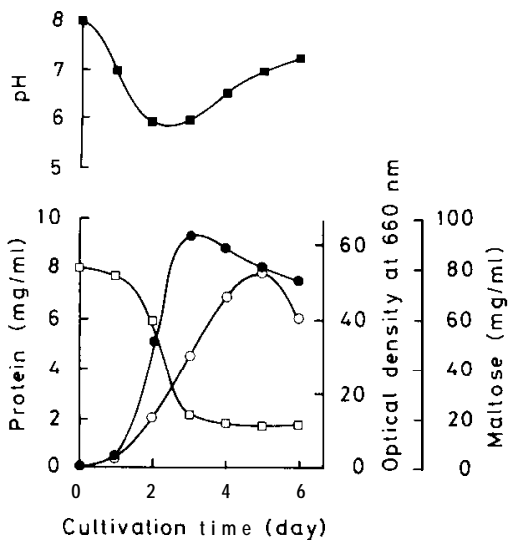

Fig. 2. Time course of extracellular protein production by strain HS-29. Cultivation was carried out under the same conditions as described in Materials and Methods. $\bigcirc$, extracellular protein; $\bigcirc$. growth; $\square$, residual sugars; $\mathbf{\square}, \mathrm{pH}$.

protein productivity of strain HS-29. After lag period of about 1 day, bacterial growth became visible and continued until 3 days. Lysis was noted as a decrease in absorbance at $660 \mathrm{~nm}$. Sugar utilization was also rapid during the phase of growth and ceased at 3 days. Extracellular protein production proceeded with the growth of cell closely and the amount of extracellular protein amounted to $7.2 \mathrm{mg}$ per $\mathrm{ml}$ of the culture broth.

\section{Some characteristics of exoprotein produced by strain HS-29}

The SDS polyacrylamide gel electrophoretic patterns of proteins obtained by protein-excretor is shown in Fig. 3. From many bands seen in the gels, the bacteria excreted various kinds of proteins and the amount of each pro-

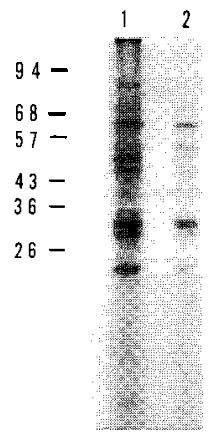

Fig. 3. Electrophoresis of proteins obtained from strain HS-29. Electrophoresis on $10 \%$ polyacrylamide gel was performed according to the method of Ames. Migration was towards the bottom. Numbers on the left of the figure show the band position of marker proteins of various mole-

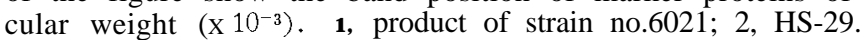


tein varied.

The amino acid composition of intra- and extracellular protein obtained from protein-excreting bacteria, HS-29, was investigated. As shown in Table 3, the amino acid composition of these proteins was different, and exoprotein contained relatively less amounts of alanine and glutamic acid compared with intracellular protein.

Table 3. Amino acid composition of strain HS-29. Intracellular protein was extracted from cell grown for $\mathbf{3}$ days, and extracellular protein was obtained from culture supernatant as described in Materials and Methods. Each amino acid content was indicated as a basis on leucine content.

\begin{tabular}{crr} 
Amino acid & Intracellular & Extracellular \\
\cline { 2 - 3 } Phe & 22 & 8 \\
Try & 9 & 8 \\
Leu & 100 & 100 \\
Ileu & 33 & 14 \\
Met & 37 & 5 \\
Val & 48 & 42 \\
Ala & 84 & 21 \\
Gly & 60 & 46 \\
Glu & 114 & 50 \\
Ser & 32 & 15 \\
Thr & 36 & 30 \\
Asp & 76 & 51 \\
Arg & 15 & 5 \\
His & 12 & 4 \\
Lys & 40 & 16 \\
\hline
\end{tabular}

\section{DISCUSSION}

Many reports have appeared on protein excretion. But such proteins described in the literatures were exoenzymes and toxins. Except enzymes and toxins, other functions have also been known and some of them are antibiotics such as various bacteriocins (Nomura, 1967) or neocarcinostatin (Ishida et al., 1965) competence factor for bacterial transformation (Perry and Slade, 1966), cell aggregating substance (Nakamura et al., 1975) and others (Goldfarb et al., 1973; Drucker, 1975).

It has been known that the rate of protein synthesis in growing bacteria is limited by the number of ribosomal RNA per cell (Stent and Brenner, 1961), and in normal cells, RNA synthesis is controlled by the molecular economy of cells. In relaxed mutants, however, the synthesis of ribosomal RNA continues even though the RNA is synthesized at the membrane, it might fail to become incorporated into ribosomes and is excreted.

In the case of the parental strain no. 6021, the productivity of extracelluIar RNA was depressed by the addition of amino acid (Hara and Ueda, 1982b). This phenomenon suggested that strain no. 6021 may be relaxed mutant. Therefore, the rate of protein synthesis in strain no. 6021 and transformant HS-29 was found to be fast. In fact, dissolved oxygen consumption by these strains was remarkably great ( $\mathrm{H}$ ara and Ueda, 1982a) and a large amount of 
cell mass from maltose resulted.

Recent experiments show that a large amount of protein can he produced in a simple medium containing a sufficient amount of carbon and nitrogen by adding glycine. In Escherichiacoli, existence of signal peptides at the N-terminal protein of the precursors is one of the common characteristics of the extracytoplasmic proteins including the outer membrane proteins, the periplasmic proteins and the inner membrane proteins.

If the roles of excreted proteins in the microbial world would be clarified, the knowledge on excretion of macromolecules such as exoproteins and DNA could be obtained. Furthermore, enzymatic techniques for introducing recombinent DNA molecules into microbial cells as autonomous replicons would have been established for mass production of biological active substances such as hormone. The possibility for mass production of drug or food protein by fermentation process which is entirely new and may be superior to processes already known.

\section{REFERENCES}

Adelberg, E. A., M. Mandel and G. C. C. Chen 1965 Optimal conditions for mutagenesis by N-methyl-N'-nitroso-N-nitrosoguanidine in Escherichia coli.Biochem. Biophys. RQ s. Comm., 18: 788-795

Ames, G. F-L. 1974 Resolution of bacterial proteins by polyacrylamide gel electrophoresis on slabs. J. Biol. Chem., 249: 634-644

Drucker, H. 1975 Regulation of extracellular proteins in Neurospracrassa: metabolic requirements of the process. J.Bacteriol., 122: 1117-1125

Dubois. M.. K. A. Gilles, J. K. Hamilton, P. A. Robers and F. Smith 1956 Colorimetric method for determination of sugars and related substances. Anal. Chem., 28: 350-356

Goldfarb, D. M., G. I. Goldberg, L. S. Chernin, L. A. Gukova. I. D. Avdienko, B. N. Kuznetsova and I. Ch. Kushner 1973 A protein produced by male strains of Escherichia coli K-12 which increases the yield of recombinants in conjugation: its nature and mode of action. Molec.Gen.Genet., 120: 211-226

Hara, T., A. Aumayr and S. Ueda 1981 Genetic transformation of Pseudomonas aeruginosa with extracellular DNA. J.Gen.Appl. Microbiol., 27: 109-114

Hara, T. and S. Ueda 1981 a RNA production by Bacillus mesentricus niger. J. Ferment.Technol., 59: 341-346

Hara, T. and S. Ueda 1981b Studies on nucleic acid production and application II. A further study of extracellular DNA production by Pseudomonas aeruginosa KYU-1. J.Appl. Microbiol., 3 : 11-18

Hara, T. and S. Ueda 1981c A study on the mechanism of DNA excretion from P. aeruginosa KYU-1. Effect of Mitomycin C on extracellular DNA production. Agric.Biol.Chem., $45:$ 2457-2461

Hara, T. and S. Ueda 1982a Effect of agitation on RNA production by Bacillus mesentricus niger. J. Fac. Agr., Kyushu Univ., 26: 79-86

Hara. T. and S. Ueda 1982b Effect of glycine on RNA production by Bacillus mesentricus niger. J. Ferment. Technol., 60: 87-88

Hara. T. and S. Ueda 1982c Transformation of Pseudomonas aeruginosa with chromosomal DNA into Bacillus subtilis. J. Fac. Agr., Kyushu Univ., 26: 151-157

Heyningen, W. E. 1970 General characteristics. In "Microbial Toxins," Vol. I. ed. by S. J. 
Ajil, S. Kadis and T. C. Montie, Academic Press, New York, pp. 1-28

Ishida, N., K. Miyazaki. K. Kumagai and M. Rikimaru 1965 Neocarzinostatin, antitumor antibiotic of high molecular weight. J. Antibiot., Ser. A, 18: 68-76

Lowry, 0. H., N. J. Rosebrough, A. L. Farr and R. J. Randall 1951 Protein measurement with the folin phenol reagent. J.Biol.Chem., 193: 265-275

Mejbaum, W. 1939 Über die Bestimmung kleiner Pentosemengen, insbesondere in Derivaten der Adenylsäure.Z.Physiol.Chem., 258: 117-120

Nakamura, J., S. Miyashiro and Y. Hirose 1975 Abstract of papers. The Annual Meeting of Agricultural Chemical Society of Japan, Sapporo. July, 1975,pp. 248 (in Japanese)

Nomura, M. 1967 Colicins and related bacteriocins. Ann. Rev. Microbiol., 21: 257-284

Perry, D. and H. D. Slade 1966 Effect of filtrates from transformable and nontransformable Streptococci on the transformation of Streptococci. J. Bacteriol., 91: 2216-2222

Pollock. M. P. 1962 Exoenzymes. In "The Bacteria," Vol. IV, ed. by I. C. Gunsalus and R. Y. Stainer, Academic Press, New York, pp. 121-178

Saito, H. and K. Miura 1963 Preparation of transforming deoxyribonucleic acid by phenol treatment. Biochim. Biophys. Acta, 72: 619-629

Schaeffer, P. 1969 Sporulation and the production of antibiotics, exoenzymes. and exotoxins. Bacteriol. Rev.. 33: 48-71

Stent, G. S. and S. Brenner 1961 A genetic locus for the regulation of ribonucleic acid synthesis. Proc. Natl. Acad.Sci., 47: 2005-2014

Ueda, S. and T. Hara 1981 Studies on nucleic acid production and application I. Production of extracellular DNA by Pseudomonas sp. KYU-1. J. Appl. Biochem., 3: 1-10

Yoshikawa. H. 1970 Temperature-sensitive mutants of Bacillus subtilis I. Multiforked replication and sequential transfer of DNA by a temperature-sensitive mutant. Proc. Natl. Acad. Sci.. 65: 206-213 